\title{
Management of uveal melanomas: cycloxygenase-2 as a potential molecular target
}

\author{
Shailendra Kapoor
}

Received: 30 March 2008/Accepted: 21 May 2012/Published online: 7 June 2012

(C) Springer Science+Business Media B.V. 2012

\section{To The Editor}

In a recent issue of International Ophthalmology, Ozdal et al. [1] wrote about cyclooxygenase-2 expression in human irradiated uveal melanomas. They reported that radiotherapy may actually decrease cycloxygenase- 2 expression in uveal melanomas. This is of great clinical significance as almost $90 \%$ of all uveal melanomas are immunoreactive for cycloxygenase-2 [2]. In fact, increased cycloxygenase-2 expression by uveal melanomas is associated with a worse prognosis.

Cycloxygenase- 2 inhibitors such as celecoxib have already been shown to inhibit tumor growth in cutaneous melanomas and cycloxygenase- 2 may very well be an ideal target molecule to inhibit carcinogenesis in uveal melanomas [3]. For instance, Marshall et al. [4] have recently demonstrated the effectiveness of a topical cycloxygenase inhibitor nepafenac in delaying tumor progression in animal models. Fernandes et al. [5] have also shown that amfenac (the active metabolite of nepafenac) increases the sensitivity of the tumor cells to radiotherapy. In fact, radiotherapy may very well have a synergistic effect with amfenac in inhibiting uveal melanoma cells. Interestingly, Souza et al. [6] have also reported increased cycloxygenase-2 expression in retinoblastomas.

\section{S. Kapoor $(\bowtie)$}

University of Illinois at Chicago, Chicago, IL 60612, USA

e-mail: shailendrakapoor@yahoo.com
Clearly, cycloxygenase-2 has a major role to play in the evolution and progression of ocular tumors. Given the massive potential that anti-cycloxygenase therapies such as nepafenac and radiotherapy have in the management of uveal melanomas, there is a clear and urgent need for further human studies to fully explore their potency and effectiveness in the management of these tumors.

\section{References}

1. Ozdal PC, Callejo S, Caissie AL, Edelstein C, Bakalian S, Vianna RN et al (2008) Cyclooxygenase-2 expression in human irradiated uveal melanomas. Int Ophthalmol 28:1-6

2. Cryan LM, Paraoan L, Hiscott P, Damato BE, Grierson I, Gray D et al (2008) Expression of COX-2 and prognostic outcome in uveal melanoma. Curr Eye Res 33:177-184

3. Wilson KS (2006) Clinical activity of celecoxib in metastatic malignant melanoma. Cancer Invest 24:740-746

4. Marshall JC, Fernandes BF, Di Cesare S, Maloney SC, Logan PT, Antecka E et al (2007) The use of a cyclooxygenase-2 inhibitor (nepafenac) in an ocular and metastatic animal model of uveal melanoma. Carcinogenesis 28:2053-2058

5. Fernandes BF, Marshall JC, Di Cesare S, Logan P, Maloney S, Burnier MN Jr (2008) Amfenac increases the radiosensitivity of uveal melanoma cell lines. Eye 22:701-706

6. Souza Filho JP, Martins MC, Correa ZM, Odashiro AN, Antecka E, Coutinho AB et al (2006) The expression of cyclooxygenase 2 in retinoblastoma: primary enucleated eyes and enucleation after conservative treatment. Am J Ophthalmol 142:625-631 